\title{
Study on Job Satisfaction of Civil Engineers in Gandaki Provincial Government, Nepal
}

\author{
Bishnu Paudel $^{1 *}$, Nirmal Prasad Baral ${ }^{1}$, Tulasi Ram Bhattarai ${ }^{2}$, Keshav Basnet ${ }^{1}$ \\ ${ }^{1}$ Infrastructure Engineering and Management Program, Department of Civil and Geomatics Engineering, Pashchimanchal Campus, Institute of \\ Engineering, Tribhuvan University, Nepal \\ ${ }^{2}$ Senior Divisional Engineer, Department of Water Resources and Irrigation, Government of Nepal
}

DOI: $10.36348 /$ sjce.2020.v04i05.003

| Received: 07.07.2020 | Accepted: 19.07.2020 | Published: 30.07.2020

*Corresponding author: Bishnu Paudel

\section{Abstract}

Better performance of infrastructure development depends on the several factors whereas job satisfaction seems one of the key factors. Large Number of Engineers was de-motivated to accept the staff adjustment policy. This study focuses to find the job satisfaction of civil Engineers in Gandaki Provincial Government. Data were collected through structured questionnaires. Questionnaires were distributed into 134 Engineers. The responses from 103 (76.87\%) respondents were documented. The study adopted descriptive and interferential statistics analytical using Statistical Program for Social Sciences (SPSS) and MS- Excel. The correlation coefficient varied between 0.292 (pay/salary) to 0.612 (Work Group). The result shows that there was significant relationship between work group and job satisfaction $(r=0.612, p<0.01)$. There was no significant difference in level of satisfaction based on demographic factors like gender, academic qualification, Age Groups, Civil engineering sub sectors, designation level and time span for total years of experience. ANOVA test was carried out to test null and alternate hypothesis $\mathrm{P}$ value for each variable was recorded greater than 0.05 . Multiple linear regression analysis was conducted considering job satisfactions as dependent variable, $\mathrm{R}$ square was recorded as of 0.582 indicates that the independent variables (predictors) such Supervisors (Bosses), Work Group, Working Conditions, Promotion Opportunities, Pay / Salary, Transfer and Posting factors used in this model explained about 58.2\% of the total variation in dependent variable job satisfaction of employees under study.

Keywords: Civil Engineer, Job satisfaction, Motivation, Predictors, Provincial Government.

Copyright @ 2020: This is an open-access article distributed under the terms of the Creative Commons Attribution license which permits unrestricted use, distribution, and reproduction in any medium for non-commercial use (NonCommercial, or CC-BY-NC) provided the original author and source are credited.

\section{INTRODUCTION}

Globally, Performance of the employees was taken good indicators for organizational success at different aspect. Sometimes there is dilemma whether technological advancement or effective management system are critical for the development model in Developing Counties. If comparing in between planned and actual performance status of the Nepalese budget since a decade, it was observed that expenditure capacity was found to be 30 to $40 \%$ indicates there was lacking the effective management whatever the attributes happening this effect. After promulgation of the Constitution of Nepal in 2015, it created pathway to transform centralized and unitary governance system to the federal system. The constitution has made provision for three levels of government - federal, provincial and local. The Constitution envisages a non-hierarchic relationship among the three levels of government based on principles of coordination, cooperation and coexistence. In this changed context, the power of the provincial governments including financial resources has increased significantly but they are facing problems to establish functional institutions of governance, deployment of the staff and planning and implementation capacity of responsibilities assigned to the respective authorities.

Physical infrastructure development is a major tool that bridges nation's prosperity and development. Status of national infrastructure system must be connected through global and regional links, if countries are benefited from the expansion of markets and trade through globalization. Infrastructure development offers the foundation on which a country can seize and capitalize on the opportunities ushered in by globalization and regional integration. Investments on large scale infrastructures are critical to enable a country in achieving long term growth and sustainable poverty reduction. It plays an important role in enabling the poor to participate in the growth process. Access to education and health which are also the indicators of 
economic development, can be vastly improved through better road, electricity, communications, water supply, and sanitation services.

Among various Professions, Civil Engineers are known as back bone of Infrastructural development. They involved at every step of project, from the project planning, designing to complete implementation of project. Engineer's breakdown project construction costs considering government regulations and potential environmental hazards. They also perform experiments to determine the parameters for a project's foundation. Engineers may work for federal, state or local governments or in the private sector at consulting or construction firms. Some holds supervisory or administrative positions, while others pursue careers in design, construction or teaching [1]. Being the part of the project, the problems have to encounter pleasant to hazardous natural phenomenon and work situation. During their job, they have to work in different environments, different topography (both in hills and terai area), different culture and that have many constraints to meet deadlines and they are particularly loaded with work responsibilities. Factors such as improper work distribution, working conditions, poor leadership and un-friendly management policies have created dissatisfaction among civil engineers. In Nepal, each year thousands of Civil engineers graduated and among them very few get the chance to enter into the government services. Civil engineers as government employees often finds themselves working in a large, bureaucratic organization in which service-delivery standards tend to be prescribed by rigid rules and regulations oriented towards standardized service and prevention of fraudulent practice from employees. Employees often expect to spend their entire working lives in the organization [2]. Since most of the government employees spend entire life in the organization, their satisfaction will affect the whole organization. Success of the organization depends on employee satisfaction.

Job satisfaction in general is the degree to which individuals enjoy their job. Broadly a person's job fulfils his dominant needs in consistent with his expectations and values. The feeling would be positive or negative depending upon whether the need is satisfied or not. It is the state of feeling resulting from appraising one's job experiences while job satisfaction results from both how we think about our work (our cognition) and how we feel about our work (our effect)[3].

In Nepal research in engineering fields like: Job satisfaction Among Civil Engineers working in Building Sector in construction firms of Nepal was conducted [4]. A Study of Job Satisfaction among civil engineers working in Hydropower Sector in Consulting Firms of Nepal had already been evaluated regarding the level of job satisfaction of civil engineers in consulting firms and contractor Sector. From these above studies it shows that, most of the Engineers are satisfied with their job but they are not satisfied with the pay system of the organization [5]. All above research gave the general perspective of an organization. Stratified sampling method and job satisfaction level at different tires of organization was not done.

Job satisfaction of Civil Engineers working in Irrigation sector under government of Nepal had already been evaluated by considering the different job level in irrigation sector under government of Nepal [6]. This research was only considered the level of satisfaction in irrigation sector engineers.

After the promulgation of constitution on $20^{\text {th }}$ Sep 2015 Nepal is being governed in the form of federal structure. In Article 302, clause 1 of constitution of Nepal provisions, for the delivery of services at the State and Local levels has been illustrated. Clause 2 of Article 302 has stated that, The Government of Nepal may, in making provisions under clause (1), arrange for the delivery of services by making adjustment of the employees serving in the government services at the time of commencement of this Constitution with the Federal, State and Local levels in accordance with law. Although the constitution has clearly defined about the service delivery in all tires of government, the employee's adjustment process has not concluded with pleasant environment. There is still shortage of staff in provincial and local level after completion of employee's adjustment in Nepal. Most of the senior staffs showed the interest in Federal government.

Nepal is in the stage of infrastructure development which will lead to overall economic development. Because of this rapid growth in the field of infrastructure development, number of job opportunities of civil engineers has grown, but at the same time, reports shows that quality of infrastructure and it's sustainability is low. In the meantime government allocated about 60 percent of its budget in the development works out of which more than seventy percent of the development budget was invested in infrastructure development. To meet the target of government, Civil Engineers have to be prepared with high level of motivation to implement the projects.

Civil Engineers working on Provincial Level have to face various problems at their project site. Political pressure, frauds, immorality, dishonesty, injustice, local issues etc, are very common issues in Engineers professional life. Aforementioned issues put immense pressure on them, which ultimately lead to anxiety and frustration among them. Dis-satisfaction leads to de-motivation to them. When they are de-motivated, they become careless in their works with negligence in supervision of works, negligence in time limit, negligence in quality of works etc. Such types of 
activities create severe problem in completion of the project and which lead to cost overrun, which ultimately affects entire growth of the nation. Most of the engineers working in federal level government do not show interest towards the adjustment in Province. Civil Engineers in Public service members are low paid compared to most of the private and multinational organizations.

This study, after completion of employee adjustment with New Federal experiences is expected to sort out the measures of satisfaction that directs the way forward to the policy maker on the reshaping demand and effective functioning of Civil Engineers under different Sector. The outcomes of the study may be useful to aware Provincial Government regarding job satisfaction among engineers working with them and necessary improvement policies regarding this can be made.

\section{MATERIALS AND METHODS Study Population}

The population of study was taken from civil engineers working under the ministry of Physical infrastructure development Gandaki Province. Total Civil Engineers currently working under Gandaki Provincial Government is 134 only. Sample size for finite population has been calculated, it was found that sample size was 100 engineers.

\section{Research Instrument}

Job satisfaction is normally measured using group meetings, surveys and interviews. Surveys and questionnaires are the preferred choice in many organizations due to the element of confidentiality they offer as well as the fact that respondents can be as candid as possible without fear of being victimized. Questionnaire survey was the major instrument for this study. Questionnaires were prepared with a view to obtain data for meeting requirement of analyzing tool and objectives of study. Questionnaire were developed including following the parameters

a) General Profile: Here participants have to provide general biographical information such as age, gender, marital status, current experience, total experience, PIS No etc.

b) Job Satisfaction by Single Global Rating Method (SGRM) In this part, direct question related to how much satisfied has been asked and participant have to response them with only one answer in five point likert type scale.

c) Job Satisfaction for different job factors: Here factor related to job satisfaction has been taken and sub divided questions are provided. In this section nine factors of job has considered and each factor has six sub questions. Respondent have to response in five point Likert type scale ranging from strongly disagree (1) to strongly agree (5) considering the each statement.

Google form methods and hard copies distribution method have been applied for the collection of data. After obtaining acceptable results from Pilot test, questionnaire had been distributed to 3 levels of officers working under Gandaki Province - Assistant $5^{\text {th }}$ level/officer $6^{\text {th }}$ level, $7^{\text {th }} / 8^{\text {th }}$ Level officer, $9^{\text {th }} / 10^{\text {th }}$ Level officer. Gazetted $1^{\text {st }}$ class officer are deputed from federal government, so they were not included in this research. Cronbach's Alpha values have been determined and the internal consistency was tested. The alpha value was noted greater than 0.7 for each sub scale.

\section{Data Analysis Tools}

The questionnaire had been distributed through Google forms and provision that only one response from each email has been documented. Questionnaires were distributed into 134 Engineers Working under Gandaki Provincial Government and 103 (76.87\%) of respondents had answered questionnaire and response been documented.

Two main factors affecting job satisfaction, namely personal/ demographic factors and job related factors have been considered. The hypothesis considers personal factors as with independent variables affecting the levels of job satisfaction. These demographic factors include gender, academic qualification, age group, sub groups, time span for total years of experience. Hypothesis have been formulated and examined accordingly. Based on each demographic factor each sub Null hypothesis was also tested.

Correlation and Multiple linear regression analysis were conducted to reveal the predictors of job satisfaction. To check the multicollinearity, tolerance and variation inflation factors (VIF) has been accessed. The residuals should be normally distributed about the predicted dependent variable scores [7]. This was checked also by looking at the histogram. The residuals should have a straight-line relationship with predicted dependent variable scores. This was tested through a normal probability plot (P-P Plot). A point line should lie in a reasonably straight diagonal line.

\section{RESULTS AND DISCUSSIONS Demographic Factors}

Interpretation of demographic factors in Gandaki Province Engineers has been presented in following sections. As can be seen in Table 1, males represented the majority of the surveyed respondents $(90.3 \%)$, while female respondents represented only $9.7 \%$ of the population. 
Table-1: Frequency Distribution Engineers Based on Demographic Factors

\begin{tabular}{|l|l|l|}
\hline Demographic Factors & Frequency & Percent \\
\hline Gender & 93 & 90.3 \\
\hline Male & 10 & 9.7 \\
\hline Female & \multicolumn{2}{|l|}{} \\
\hline Academic Qualification & 15.53 \\
\hline Diploma in Civil Engineering & 16 & 53.40 \\
\hline Bachelor in Civil Engineering & 55 & 31.07 \\
\hline Masters in Civil Engineering & 32 & 1.9 \\
\hline Age Group & 2 & 67.0 \\
\hline 25 yrs. or less & 69 & 16.5 \\
\hline 26 to 35 yrs & 17 & 14.6 \\
\hline 36 to 45 yrs & 15 \\
\hline 46 to 55 yrs & 7 & 6.8 \\
\hline Total years of experience & 36 & 35.0 \\
\hline 1 to 3 years & 24 & 23.3 \\
\hline 3 to 5 years & 36 & 35.0 \\
\hline 5 to 10 years & \\
\hline Over 10 years & \\
\hline
\end{tabular}

Data in Table 1 indicates that there were fewer female Engineers in the Gandaki Provincial Government compared to male Engineer. It has been found that majority of the respondent $55(53.4 \%)$ have Bachelor Degree whereas $32(31.1 \%)$ have Master degree and only 16 (15.5\%) have Diploma in Civil Engineering as academic qualification. It concludes that majority of the respondent have completed Bachelor degree in Civil Engineering. The majority of the respondents $(\mathrm{n}=69$ or $67.0 \%)$ fall in the age category 26-35 years. This is followed by $17(16.5 \%)$ of the respondents in the age category $36-45$ years. The age category $46-55$ years old, constitutes $14.6 \%(n=15)$ of the sample. The minority of the respondents $(n=5$ or $5.9 \%$ ) fall in the age category of 25 years and younger. From the ensuing results it can therefore be concluded that the majority of the workforce participating in the study is fairly young, ranging below the ages 35 years old (cumulatively more 68.9\%). Data shown that 7 $(6.8 \%)$ and $36(35 \%)$ of respondent have 1 to 3 years. and 3 to 5 years of experience respectively. Engineers having 5 to 10 years of experience were 24 (23.3\%), while $36(35.0 \%)$ respondent have over 10 years experience. It concludes that majority of Civil Engineers in Gandaki Provincial Government Engineers in have had more than five years of experience cumulatively $60(58.3 \%)$.

\section{Job Satisfaction Level and Frequency Distribution}

Table 2 shows the frequency distribution for the job satisfaction by single global rating method corresponding to the questionnaire.

Table-2: Frequency Distribution of Civil Engineers Based on Response in SGRM

\begin{tabular}{|l|l|l|}
\hline Job satisfaction by SGRM & Frequency & Percent \\
\hline Highly Dissatisfied & 4 & 3.9 \\
\hline Dissatisfied & 16 & 15.5 \\
\hline Neither Dissatisfied Nor Satisfied & 39 & 37.9 \\
\hline Satisfied & 44 & 42.7 \\
\hline Total & 103 & 100.0 \\
\hline
\end{tabular}

From Table 2, it was observed that $4(3.9 \%)$ were highly dissatisfied, $16(15.5 \%)$ were dissatisfied, $39(37.9 \%)$ were neutral while $44(42.7 \%)$ are satisfied. This result reflects that $20(19.4 \%)$ respondents were dissatisfied in their job, while $44(42.7 \%)$ respondents were satisfied.

\section{Level of Satisfaction in Different Job Related Factors}

Satisfaction level in different job related factors was accessed and their satisfaction level based on the response in 9 factors has been presented in Table 3. Since co-workers, supervisor/boss and communications mean values are greater than 3 it appears that civil engineers working in Gandaki Provincial Government were relatively satisfied with their job in such variable, while dissatisfied with the other factors. Pay systems have least mean which appears that civil engineers were less satisfied with the pay they received. 
Table-3: Descriptive Statistics for Job Related Variables

\begin{tabular}{|l|l|l|c|l|}
\hline Descriptive Statistics & $\mathrm{N}$ & Mean & Standard Deviation & Variance \\
\hline Variable & 103 & 2.65 & 0.58 & 0.33 \\
\hline Job Itself & 103 & 2.08 & 0.59 & 0.33 \\
\hline Pay / Salary & 103 & 2.41 & 0.68 & 0.46 \\
\hline Promotion Opportunities & 103 & 3.81 & 0.43 & 0.18 \\
\hline Work Group & 103 & 3.29 & 0.63 & 0.40 \\
\hline Supervision/ Supervisors & 103 & 2.87 & 0.56 & 0.32 \\
\hline Working Conditions & 103 & 2.52 & 0.49 & 0.24 \\
\hline Transfer and Posting & 103 & 2.43 & 0.67 & 0.43 \\
\hline Professional Development & 103 & 3.40 & 0.52 & 0.27 \\
\hline Communication & & & \\
\hline
\end{tabular}

As observed in Table 3, engineers are less satisfied with the promotions opportunities, job nature, professional development and transfer and posting sub scale factors. The level of job satisfaction in different facets of job related variable has varied significantly. Engineers working in Gandaki Provincial Governments are dissatisfied with their salary. Engineers have shown considerable level of satisfaction in work group. In single organization there was different level of engineering officials which make easy in understanding of problem and in decision making.
Table 4 shows that on average Job Satisfaction score of civil engineers was 3.19 out of 5 with standard deviation 0.841 and coefficient of variance equal to 0.707. It indicates that on average officers were satisfied however responses are varying by $70.7 \%$. Job satisfaction was also measured indirectly as summation job factor method which result mean of 2.86 which means respondent were less satisfied to their job. The variation of results in summation job factor method is $17.7 \%$ only.

Table-4: Level of Job Satisfaction in Gandaki Provincial Government Civil Engineers

\begin{tabular}{|l|l|l|l|l|l|}
\hline Variables & N & Mean & Standard. Deviation & Variance \\
\hline Job Satisfaction by Summation Job Factors Method (SJFM) & 103 & 2.86 & 0.421 & 0.177 \\
\hline job Satisfaction by Single Global Rating Method (SGRM) & 103 & 3.19 & 0.841 & 0.707 \\
\hline
\end{tabular}

The Pearson correlation coefficient between nine job related factors as independent variable and job satisfaction as dependent variable was determined by analyzing the primary survey data in SPSS. The correlation coefficients varied between 0.611 (Supervision) to 0.306 (pay).

\section{Measure of Correlation between Job satisfaction and Different Job Related factors}

The proposed model of job satisfaction, in this research, shows that personal variables, as independent variables, influence employees' job satisfaction Hypothesis one tests whether there are relationships between personal variables (independent variables) and Job Satisfaction (the dependant variable) by using bivariate analyses.
The variables were individually tested, in order to investigate any significant difference in Job Satisfaction among different groups, the t-test and ANOVA tests were used. As there were six personal factors, six sub-null hypotheses were generated.

The independent t-test was used to examine whether the means of Job Satisfaction between men and women were different. Table 5 shows that there were no statistically significant difference in the means of Job Satisfaction between the male and female Engineers working in Gandaki Provincial Government. Though both groups numerically different level levels of satisfaction towards their job (2.85 and 3.00) statistically mean was not significantly different $(\mathrm{p}=$ $0.285>0.05)$.

Table-5: Relationship between Job Related Variable Gender and Job Satisfaction

\begin{tabular}{|l|l|l|l|l|l|l|}
\hline Gender & $\mathbf{N}$ & Mean & SD & t & df & Sig \\
\hline Male & 93 & 2.85 & 0.415 & -1.075 & 101 & 0.285 \\
\cline { 1 - 3 } Female & 10 & 3.00 & 0.471 & & & \\
\hline
\end{tabular}

The three educational level groups were subjected to ANOVA analysis to determine which group differed significantly. Results found no significant differences in job satisfaction among levels of education.
The four age groups, three sub group and three designation levels were subjected to ANOVA analysis to determine which group differed significantly. Table 6 shows no significant differences in Job Satisfaction between levels of age group, sub group and designation level. 
The four time span of total years of experience was subjected to one way ANOVA test to determine which group differed significantly. Results found that there were no significant differences in Job Satisfaction between different years of experience of civil engineering.

Table-6: ANOVA test results of variables

\begin{tabular}{|c|c|c|c|c|c|c|}
\hline Academic qualification & $\mathbf{N}$ & Mean & Standard. Deviation & Std. Error & $\mathbf{F}$ & Sig \\
\hline $\mathrm{DCE}$ & 16 & 2.92 & 0.435 & 0.109 & \multirow[t]{3}{*}{0.631} & \multirow[t]{3}{*}{0.534} \\
\hline $\mathrm{BCE}$ & 55 & 2.82 & 0.391 & 0.053 & & \\
\hline MSC & 32 & 2.91 & 0.467 & 0.083 & & \\
\hline Age Groups & $\mathbf{N}$ & Mean & Standard. Deviation & Std. Error & $\mathbf{F}$ & Sig \\
\hline 25 yrs. or less & 2 & 3.00 & 0.000 & 0.000 & \multirow[t]{4}{*}{1.230} & \multirow[t]{4}{*}{0.303} \\
\hline 26 to 35 yrs & 69 & 2.82 & 0.421 & 0.051 & & \\
\hline 36 to $45 \mathrm{yrs}$ & 17 & 2.89 & 0.337 & 0.082 & & \\
\hline 46 to $55 \mathrm{yrs}$ & 15 & 3.04 & 0.503 & 0.130 & & \\
\hline Sub Groups & $\mathbf{N}$ & Mean & Standard. Deviation & Std. Error & $\mathbf{F}$ & Sig \\
\hline General & 41 & 2.95 & 0.384 & 0.060 & \multirow[t]{3}{*}{1.609} & \multirow[t]{3}{*}{0.205} \\
\hline Sanitary & 14 & 2.86 & 0.361 & 0.097 & & \\
\hline Irrigation & 48 & 2.79 & 0.459 & 0.066 & & \\
\hline Designation Level & $\mathbf{N}$ & Mean & Standard. Deviation & Std. Error & $\mathbf{F}$ & Sig \\
\hline $5 / 6^{\text {th }}$ Level officer & 40 & 2.85 & 0.427 & 0.068 & \multirow[t]{3}{*}{2.137} & \multirow[t]{3}{*}{0.123} \\
\hline $7 / 8^{\text {th }}$ Level officer & 46 & 2.81 & 0.383 & 0.056 & & \\
\hline $9 / 10^{\text {th }}$ Level officer & 17 & 3.05 & 0.477 & 0.116 & & \\
\hline Total Years of Experience & $\mathbf{N}$ & Mean & Standard. Deviation & Std. Error & $\mathbf{F}$ & Sig \\
\hline 1 to 3 yrs & 7 & 2.71 & 0.488 & 0.184 & \multirow[t]{4}{*}{1.152} & \multirow[t]{4}{*}{0.332} \\
\hline 3 to 5 yrs & 36 & 2.79 & 0.406 & 0.068 & & \\
\hline 5 to 10 yrs & 24 & 2.92 & 0.282 & 0.058 & & \\
\hline Over 10 years & 36 & 2.93 & 0.491 & 0.082 & & \\
\hline
\end{tabular}

\section{Multiple linear Regressions for explaining Job satisfaction of Engineers}

The multiple regression analysis was conducted based on response from respondents. The Job satisfaction was considered as dependent variable and different job related factors were considered as independent variables.
Step wise regression analysis was conducted using SPSS between the predictors and job satisfaction. Model 6 was considered as final model, which was included six independent variables such as Supervisors, Work Group, Working Conditions, Promotion Opportunities, Salary, Transfer and Posting as predictors in final model. Table 7 has illustrated the findings.

Table-7: Modal Summary for Regression Analysis between Job Satisfaction and its Predictors

\begin{tabular}{|l|l|l|l|l|l|}
\hline Model & R & R Square & $\begin{array}{l}\text { Adjusted R } \\
\text { Square }\end{array}$ & $\begin{array}{l}\text { Standard. Error of } \\
\text { the Estimate }\end{array}$ & Durbin-Watson \\
\hline 6 & $0.763^{\mathrm{f}}$ & 0.582 & 0.556 & 0.286 & 2.010 \\
\hline $\begin{array}{l}\text { f. Predictors: (Constant), Supervisors, Work Group, Working Conditions , Promotion } \\
\text { Opportunities, Salary, Transfer and Posting }\end{array}$ \\
\hline
\end{tabular}

The results as shown that, the $\mathrm{R}$ square value of 0.582 indicates that the independent variables (predictors) such Supervisors (Bosses), Work Group, Working Conditions, Promotion Opportunities, Pay/Salary, Transfer and Posting factors used in this model explained about $58.2 \%$ of the total variation in dependent variable job satisfaction of employees under study and the remaining $41.8 \%$ was explained by other factors which are not considered in this study. It means that $55.6 \%$ of the total variation of the dependent variable job satisfaction of employees can be explained by the regression model including the above independent variables. Though we had selected nine variables in job related factors, the variable like job itself, communication and professional development/ career planning have not significant affects in regression model. Though total variability in dependent variable based on predictors was $55.6 \%$, three variables have not significant in regression model. From this model it can be concluded that more others factors have to be considered for perfect model. The value of adjusted $\mathrm{R}$ square is higher than the benchmark of 0.5 which is sufficiently explainable enough for the regression model [8].

Using the values of the coefficients $(\beta)$ from the regression coefficients in Table 8 , the estimated multiple linear regression equation is as follows: 
$\mathrm{Y}=0.240+0.123 \mathrm{X}_{1}+0.252 \mathrm{X}_{2}+0.117 \mathrm{X}_{3}+0.142 \mathrm{X}_{4}+$

$\mathrm{X}_{2}=$ Work Group

$\mathrm{X}_{3}=$ Working Conditions

$0.117 \mathrm{X}_{5}+0.107 \mathrm{X}_{6} \ldots .(1)$

$\mathrm{X}_{4}=$ Promotion Opportunities

$\mathrm{Y}=$ Job Satisfaction

$\mathrm{X}_{5}=$ Pay / Salary

$\mathrm{X}_{1}=$ Supervisors

$\mathrm{X}_{6}=$ Transfer and Posting

Table-8: Multivariate regression coefficients with Job satisfaction as dependent variable

\begin{tabular}{|c|c|c|c|c|c|c|}
\hline \multirow[t]{2}{*}{ Model (Predictors) } & \multicolumn{2}{|c|}{$\begin{array}{l}\text { Un standardized } \\
\text { Coefficients }\end{array}$} & \multirow[t]{2}{*}{$\mathbf{t}$} & \multirow[t]{2}{*}{ Sig. } & \multicolumn{2}{|c|}{ 95.0\% Confidence Interval for B } \\
\hline & $\beta$ & Std. Error & & & Lower Bound & Upper Bound \\
\hline (Constant) & 0.240 & 0.247 & 0.971 & 0.334 & -0.250 & 0.729 \\
\hline Supervisors & 0.123 & 0.049 & 2.495 & 0.014 & 0.025 & 0.222 \\
\hline Work Group & 0.252 & 0.053 & 4.780 & 0.000 & 0.147 & 0.356 \\
\hline Working Conditions & 0.117 & 0.050 & 2.330 & 0.022 & 0.017 & 0.216 \\
\hline Promotion Opportunities & 0.142 & 0.062 & 2.288 & 0.024 & 0.019 & 0.265 \\
\hline Pay / Salary & 0.117 & 0.046 & 2.558 & 0.012 & 0.026 & 0.207 \\
\hline Transfer and Posting & 0.107 & 0.051 & 2.094 & 0.039 & 0.006 & 0.209 \\
\hline
\end{tabular}

\section{Test of Presence of Multicollinearity}

The correlation matrix for all the independent variables used in this analysis shows that none of the variables has a correlation of 0.8 and above. In addition, there are two common measures used for assessing co linearity, namely, tolerance value and VIF. The tolerance value was checked and found to be above 0.1 suggesting no possibility of multicollinearity. The VIF value was less than 10 indicating no multicolinearity therefore; all variables were retained [9].

Table-9: Table of tolerance value and variation inflation factor (VIF)

\begin{tabular}{|l|l|l|}
\hline \multirow{2}{*}{ Model } & \multicolumn{2}{l|}{$\begin{array}{l}\text { Collinearity } \\
\text { Statistics }\end{array}$} \\
\cline { 2 - 3 } & Tolerance & VIF \\
\hline (Constant) & & \\
\hline Job Itself & 0.601 & 1.665 \\
\hline Pay / Salary & 0.853 & 1.172 \\
\hline Promotion Opportunities & 0.761 & 1.313 \\
\hline Work Group & 0.735 & 1.361 \\
\hline Supervisors & 0.486 & 2.057 \\
\hline Working Conditions & 0.528 & 1.894 \\
\hline Transfer and Posting & 0.614 & 1.628 \\
\hline $\begin{array}{l}\text { Professional Development /Career } \\
\text { Planning }\end{array}$ & 0.682 & 1.467 \\
\hline Communication & 0.545 & 1.834 \\
\hline
\end{tabular}

A graphical tool for assessing normality is the normal probability plot, a percentile - percentile plot ( $\mathrm{P}$ $\mathrm{P}$ Plot) or the cumulative probability plots of residuals (P-P plot) of the standardized data against the standard normal distribution. For normal data, the points plotted in the P-P plot should fall approximately on a straight line, indicating high positive correlation. For the research perspective, we want to show that our data set are normally distributed. Figure 1 shows how the residuals are deviate from the normal line. From Fig 2, there was no huge deviation of residuals from normal line. Also, it can be seen that the data set was going through the origin. So, it indicates that the residuals were approximately normally distributed.

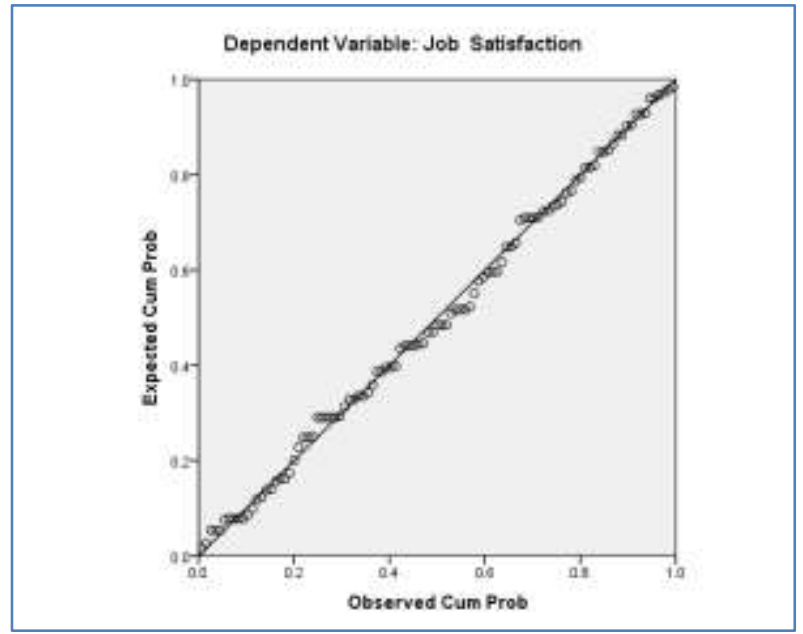

Fig-1: Normal P-P Plot for Job Satisfaction

Normality was also checked by assessing the histogram in Fig 2 for which the Job Satisfaction 
variable appears to be normally distributed in the population (a bell-shaped curve).

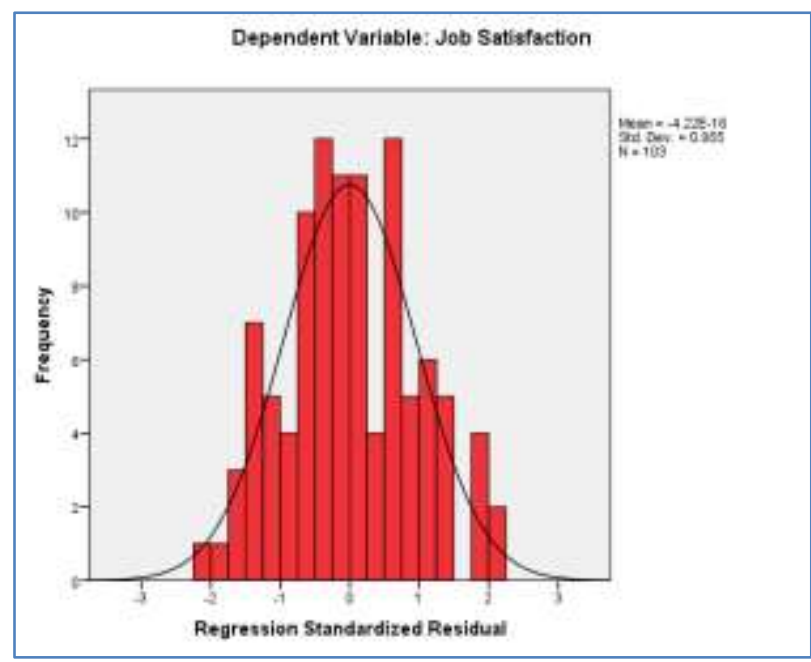

Fig-2: Histogram for Job Satisfaction

By plotting the standardized residuals against the predicted values as shown in Fig-, the scatter plot of residual versus predicted value shows that the errors were uniformly distributed over the entire range of the predicted value and it found that there was no clear relationship between the residuals and the predicted values. Therefore, the results suggest that the assumption of homoscedatisity should be met in the study. It was the indication of absence of heteroscedasticity.

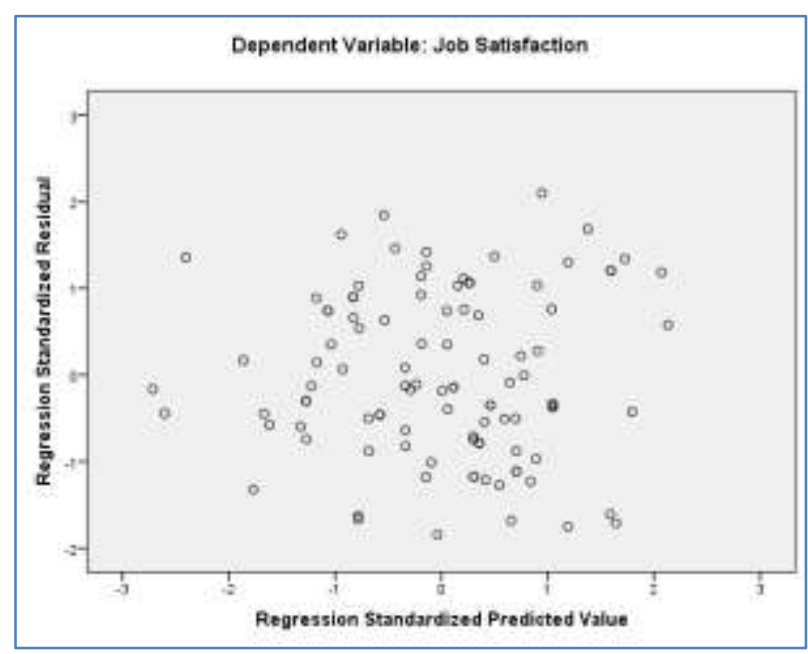

Fig-3: Scatterplot for Job Satisfaction

\section{CONCLUSION AND RECOMENDATIONS}

This study included assessment of job satisfaction of Civil Engineers working in Gandaki Provincial government. The research instrument in this research was questionnaire survey. The questionnaire was distributed to the civil Engineers working under ministry of physical infrastructure development, Gandaki Province. The response was collected via hard copies submission and Google forms and $76.87 \%$ of respondents responded the questionnaire during research period. The questionnaire has been distributed towards three sub group the response from each sub group has been collected and analysis was performed in SPSS. Overall Gandaki provincial government civil engineer's satisfaction level and factors affecting their job satisfaction was accessed using descriptive and interferential statistics.

As the objectives of study was to access the status job satisfaction based of different demographic factors like gender, designation level etc. Though both groups male and females numerically different level levels of satisfaction towards their job (2.85 and 3.00) statistically mean was not significantly different $(\mathrm{p}=$ 0.285> 0.05). Similarly there was no significant difference in level of satisfaction based on academic qualification, Age Groups, Civil engineering sub sectors, designation level and time span for total years of experience. One way ANOVA test was carried out to test null and alternate hypothesis $\mathrm{P}$ value for each variable was recorded greater than 0.05 .

Job satisfaction was measured by two approaches in this research namely single global rating method and summation job factors method. The satisfaction level was 3.19 in single global rating method and 2.86 in summation job factors method. Nine job related factors was considered in research, among these greater satisfaction was recorded in work group factors with average value 3.75 out of 5 and lesser satisfaction in salary with average 2.24 in 5 . Results based on single global rating method $42.7 \%$ of engineers were satisfied with their job and $19.4 \%$ were dissatisfied with their job. Moreover $37.9 \%$ were neither satisfied nor dissatisfied with their job.

Correlation coefficient considering the job satisfaction as dependent variable and nine job related variable as independent variable was carried out. All factors were shown the positive correlation with job satisfaction within $1 \%$ level of significance. Step wise multiple linear regression analysis was conducted using SPSS between the predictors and job satisfaction. Modal 6 was considered as final model, which was included six independent variables such as Supervisors, Work Group, Working Conditions, Promotion Opportunities, Salary, Transfer and Posting as predictors in final model.

$\mathrm{R}$ square value of 0.582 indicates that the independent variables (predictors) such Supervisors (Bosses), Work Group, Working Conditions, Promotion Opportunities, Pay / Salary, Transfer and Posting factors used in this model explained about $58.2 \%$ of the total variation in dependent variable job satisfaction of employees under study and the remaining $41.8 \%$ was explained by other factors which are not considered in this study. It means that $55.6 \%$ of the total variation of the dependent variable job satisfaction of employees 
can be explained by the regression model including the above independent variables. Though we had selected nine variables in job related factors, the variable like job it, communication and professional development/ career planning have not significant affects in regression model. Though total variability in dependent variable based on predictors was $55.6 \%$, three variables have not significant in regression model. From this model it can be concluded that more others factors have to be considered for perfect model.

\section{REFERENCES}

1. Civil Engineer Career Rankings. (2019). Salary, Reviews and Advic US News Best Jobs. from https://money.usnews.com/careers/best-jobs/civilengineer Retrieved (December 1-2019).

2. Mak, C. K. Y., \& Hong, J. F. L. (2010). An investigation of Determinants of Job Satisfaction for Macau civil servants, Euro Asia Journal of Management, 20 (2), 175-191.

3. Locke, E. A. (1969). What is job satisfaction?. Organizational behavior and human performance, 4(4), 309-336.
4. Bhatta, A. K., Shrestha, S. K., \& Mishra, A. K. (2018). Job Satisfaction Among Civil Engineers Working in Building Sector in Construction Firms of Nepal. J Adv Res Civil Envi Engr, 5(3), 9-17.

5. Thapa, P., \& Shrestha, S. K. (2018). A Study of Job Satisfaction among Civil Engineers Working in Hydropower Sector in Consulting Firms. Journal of the Institute of Engineering, 14(1), 165-169.

6. Paudel, A., Koirala, M. P., \& Shrestha, S. K. (2019). Job Satisfaction of Civil Engineers Working in Irrigation Sector Under Government of Nepal. International Journal of Engineering Research \& Technology (IJERT), 8(6), 53-57.

7. Pallant, J. (2001). SPSS Survival Manual: A Step by Step Guide to Data Analysis Using Spss for Windows, Open University Press.

8. F, J., Jr, H., C, W., Black, J, B., \& E, B. R. (2014). Multivariate Data Analysis (MVDA). Pearson New International Edition.

9. Field, A. (2009). Discovering Statistics Using SPSS. In SAGE Publications Ltd,B 1/I 1 Mohan Cooperative Industrial Area Mathura Road New Delhi. 